\section{Strategic management accounting practices: a literature review and opportunity for future research}

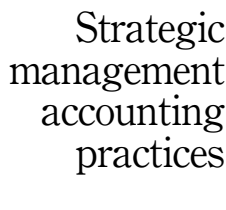

109

\author{
Department of Business Administration, Stamford University Bangladesh, \\ Dhaka, Bangladesh \\ Md. Mohobbot Ali \\ Melbourne Institute of Technology, Melbourne, Australia, and \\ Dewan Mahboob Hossain \\ Accounting and Information Systems, Dhaka University, Dhaka, Bangladesh
}

\begin{abstract}
Purpose - The purpose of this study is to review the empirical studies that have focused on the adoption, benefits and contingencies of strategic management accounting (SMA) practices and the effects of adoption on firm performance.

Design/methodology/approach - The study has highlighted empirical studies conducted on SMA practices in the context of both developed [1] and developing economies. In reviewing the literature, the study focuses on the findings of developed economy separately from that of developing economy to get more insight into the differences in the practices of the two set of economies. Based on the review, avenues for future research studies are outlined.

Findings - The review of extant literature reveals that several SMA techniques such as competitor accounting, strategic pricing, benchmarking and customer accounting have been highly or moderately adopted in several developed countries while majority of other techniques remained at the bottom line of the adoption status. However, the review demonstrates substantial differences in the SMA practices between the two set of economies in terms of the level of adoption, contingent factors and the effects of adoption.

Originality/value - The study attempts to focus on empirical studies that have concentrated exclusively on SMA practices. The adoption status, benefits derived, contingent factors affecting the adoption decision and the effect of adopting a package of SMA techniques on several aspects of firm performance are presented in the context of both developed and developing economies.
\end{abstract}

Keywords Strategic management accounting, Contingent factors, Adoption, Effect of adoption, Literature review

Paper type Literature review

\section{Introduction}

In the late 1980s, management accounting (MAC) faced considerable challenges when Johnson and Kaplan (1987) claimed that MAC has lost its relevance in the changed business environment. Rapid advancement in technology and its use in operations and the use of personal computers in information processing (Ashton et al., 1995) left the MAC tools obsolete in meeting the information needs of management specifically in firms that were using computerized and innovative manufacturing processes (Kaplan, 1984; Johnson and Kaplan, 1987). This fostered the revolution of MAC in 1980s (Kaplan, 1984; Johnson and Kaplan, 1987). This revolution took place on both sides of the Atlantic (USA and UK) and resulted in the

(C) Md. Mamunur Rashid, Md. Mohobbot Ali and Dewan Mahboob Hossain. Published in Asian Journal of Accounting Research. Published by Emerald Publishing Limited. This article is published under the Creative Commons Attribution (CC BY 4.0) licence. Anyone may reproduce, distribute, translate and create derivative works of this article (for both commercial and non-commercial purposes), subject to full attribution to the original publication and authors. The full terms of this licence may be seen at http:// creativecommons.org/licences/by/4.0/legalcode
Received 22 June 2019 Revised 10 March 2020 22 September 2020 6 October 2020

Accepted 14 October 2020 
AJAR

6,1 emergence of a number of new MAC techniques (Langfield-Smith, 2008). These new innovations in the field of MAC were termed as "strategic management accounting (SMA)" in the UK and "strategic cost management (SCM)" in the USA ((Langfield-Smith, 2008).

Simmonds (1981) was the first to use the term "strategic management accounting" in an influential paper published in the UK professional magazine "Management Accounting" which includes the provision of analyzing competitors data in developing and monitoring business strategy. Surprisingly, it took 19 years to investigate the adoption status of SMA techniques since its inception. Guilding et al. (2000) were the first to provide an empirical evidence on the usage of (12) SMA techniques in the context of New Zealand, USA and UK. Their work was followed by several other researchers (e.g. Cravens and Guilding, 2001; Guilding and McManus, 2002; Cadez and Guilding, 2007; Chinquini and Tenucci, 2010; Cescon et al., 2019) who examined the extent of adoption and/or benefits and/or contingent factors, and/or the effects of adoption of such innovative practices on firm performance. However, as Coad (1996, p. 392) holds that "SMA is an emerging field whose boundaries are loose and, as yet, there is no unified view of what it is or how it might develop. The existing literature in the field is both disparate and disjointed". Therefore, it is necessary to organize the extant literature of SMA practices to learn about the current status and opportunities for future research. Moreover, as several prior studies (e.g. Cadez and Guilding, 2008; Aykan and Aksoylu, 2013; Turner et al., 2017; Amanollah Nejad Kalkhouran et al., 2017; Alamri, 2019) documented a positive direct and/or mediating effect of SMA usage on several aspects of firm performance, the identification of the adoption status and factors influencing the adoption decision of SMA techniques noticed by the extant literature can be of particular importance to the decision-makers. More importantly, the directions for further research in this field in the face of fourth industrial revolution and climate change can contribute positively to the further development of this emerging field of research.

The review method employed in this study is, in essence, a mixed method. We reviewed articles published on SMA as a package in 22 influential accounting journals (Zawawi and Hoque, 2010) between 1981 and 2019 (both years inclusive). We analyzed the findings of those articles using the analytical method adopted by Shields (1997) and Zawawi and Hoque (2010) and conventional tabulation. The findings revealed a comparatively lower usage of SMA techniques across the globe with moderate and higher usage of competitor- and customer-focused techniques, benchmarking and strategic pricing in several developed countries. Whereas the status of such practices in the context of developing economies remain unexplored. The variations in the contingencies affecting the adoption decision and effect on firm performance were also noticeable.

Our study contributes to the extant literature in several ways. First, the study provides an overview of the present status of adoption of SMA practices across the globe. Second, considering the differences in the two types of economies (developed and developing economies); our study has highlighted the factors affecting the decision to adopt SMA techniques separately in the context of each set of economy. Finally, the study outlines opportunities for future research on the practicality of SMA including its way forward in relation to the new development such as cloud-based solutions, big data and analytics, artificial intelligence (AI), new business development, the role of management accountant as a business partner and in the face of climate change.

The remainder of this paper is organized as follows. Section 2 presents the review method followed in this study. Section 3 presents and analyzes the findings followed by Section 4 which provides a summary of the findings and suggestions for further research. Section 5 presents the conclusion and limitations of the study.

\section{Review method}

The present review, indeed, employed a mixed method approach. The journals and articles have been selected following the analytical framework of Shields (1997) and Zawawi and 
Hoque (2010). We searched for any article published on SMA techniques from 1981 to 2019 using search engines like Google, Google Scholar, etc. Moreover, we also visited all the issues of 22 influential accounting journals studied by Zawawi and Hoque (2010). We used the "Australian Business Deans Council (ABDC)" ranked journal list as a minimum criterion to be included to the list of articles reviewed in the present study. Table 1 reports the results of the above searches. As can be seen in Table 1, 19 articles have been published on the adoption, benefits, contingencies and effect of SMA practices between 1981 and 2019, both years inclusive. Of these 19 articles, Journal of Accounting and Organizational Change has published the highest number (six) of articles on SMA practices, followed by Accounting, Organization and Society (three) and Asian Review of Accounting (two) (see Table 1).

Each of the remaining journals published only a single article on SMA practices during the period of the study. Accordingly, it can be held that the adoption, benefits and contingencies of SMA practices and their effects on firm performance remained unexplored in many countries of the world. To analyze the findings of these articles, we employed conventional methodology on several grounds. First, the volume of articles focusing on the factors contingent to the adoption of SMA techniques is extremely low (only 13). Of these articles, two have focused merely on a particular group of techniques (e.g. competitor or customer). Second, many (four) of these articles did not employ regression analysis which motivates us not to employ more scientific method such as meta-analysis. Accordingly, drawing conclusion from those studies employing more advanced method like meta-analysis seems to be hardly possible. Third, the variables used in these studies are also diversified except for the strategy type which further stimulates not to employ advanced methodology. Despite the use of conventional methodology, we present the findings of the extant SMA literature separately for the firms in developed and developing economy on the ground that they differ in terms of political, cultural and economic factors that influence the understanding of management accounting practices (MAPs) (Hopper et al., 2009) (see Figure 1).

\section{Findings}

\subsection{Adoption status and perceived benefits}

3.1.1 In the context of developed economy. Table 2 presents the adoption status of SMA techniques between 1981 and 2019, both years inclusive. As can be seen in Table 2, all of the studies have been conducted in the context of developed economies (e.g. US, UK, New Zealand, Slovenia and Italy). While several of these studies (e.g. Cravens and Guilding, 2001; Cadez and Guilding 2008; Chinquini and Tenucci, 2010; Cadez and Guilding, 2012) have

\begin{tabular}{lcc}
\hline Journals & Coverage & Articles on SMA* \\
\hline Accounting, Organizations and Society & $1981-2019$ & 3 \\
Advances in Management Accounting & $1981-2019$ & 1 \\
Australian Journal of Business and Management Research & $1981-2019$ & 1 \\
Asian Review of Accounting & $1981-2019$ & 2 \\
Baltic Journal of Management & $1981-2019$ & 1 \\
Journal of Accounting and Organizational Change & $1981-2019$ & 6 \\
Journal of Management and Governance & $1981-2019$ & 1 \\
International Journal of Hospitality Management & $1981-2019$ & 1 \\
Industrial Management and Data Systems & $1981-2019$ & 1 \\
Management Accounting Research & $1981-2019$ & 1 \\
Munich Personal RePEc Archive & $1981-2019$ & 1 \\
Total & & 19
\end{tabular}

Note(s): * Articles focused on the adoption, benefits, contingent factors to adoption and effects of adoption on performance

Strategic
management accounting practices 
AJAR

6,1

\section{2}

focused solely on the SMA practices of a specific country, others (e.g. Guilding et al., 2000; Cadez and Guilding, 2007) have focused on the SMA practices of multiple countries.

Guilding et al. (2000) were the first to provide empirical evidence on the use of SMA techniques internationally (US, UK and New Zealand). The study was conducted on the adoption and perceived merit of 12 SMA techniques among the largest companies in New Zealand, USA and UK. They separated SMA techniques from traditional MAC based on the criteria of having some strategic orientations including environmental orientation, competitors focused, long-term and forward-looking orientation (Guilding et al., 2000). The findings revealed fairly similar level of SMA usage among the surveyed countries. Competitor-focused accounting and strategic pricing were the most widely used SMA techniques in all the sample countries (see Table 2).

The study also confirmed that most of the SMA techniques were not widely used in the sample companies. Despite this lower usage, the sample companies demonstrate positive perception with respect to the perceived benefits derived from the use of SMA techniques. This positive perception is reflected in the scores assigned by the sample companies. The perceived merit scores of SMA usage are substantially greater than the usage scores. Moreover, the above average scores of perceived benefits of "lower usage SMA techniques" signify their potential usage in the sample countries in the foreseeable future (Guilding et al., 2000) (see Table 3).

One year later, Cravens and Guilding (2001) conducted another survey in the USA by adding three more techniques [activity-based costing $(\mathrm{ABC})$, benchmarking and integrated performance measurement (IPM)] to the list of SMA techniques studied by Guilding et al. (2000). Their study documented that competitive position monitoring (CPM), competitor performance appraisal based on published financial statements (CPAFS) and benchmarking are the most widely used SMA techniques in the USA. This finding confirmed the popularity of competitor-focused SMA techniques in the USA.

Cadez and Guilding (2007) added three more techniques [customer profitability analysis (CPA), lifetime customer profitability analysis (LTCPA) and valuation of customers as assets (VCA)] to the list of 15 SMA techniques studied by Cravens and Guilding (2001). They surveyed the adoption of these SMA techniques in the largest (in terms of total revenue) manufacturing firms in Slovenia and Australia. Akin to the findings of Guilding et al. (2000) and Cravens and Guilding (2001), competitor-focused techniques, benchmarking and strategic pricing were found at the top of the list of SMA techniques in both the countries. However, costing-oriented SMA techniques were highly adopted in the Slovenian companies as compared to their counterparts in Australia.

In the same year, Chinquini and Tenucci (2007) conducted a survey which focused on the SMA usage of the largest Italian manufacturing firms. They merged three customer-focused SMA techniques (CPA, LTCPA and VCA) into a single technique under the head of "customer

Figure 1.

Structure of literature review on SMA practices

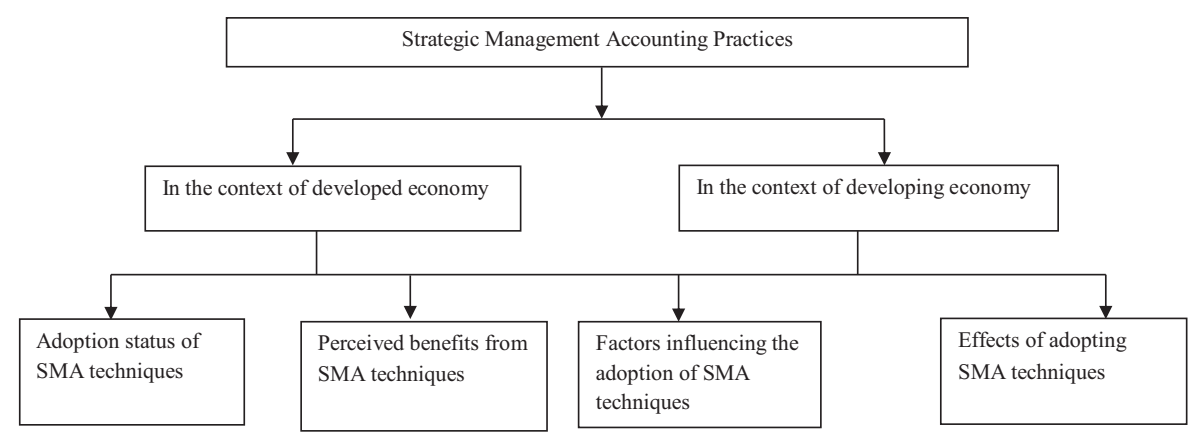




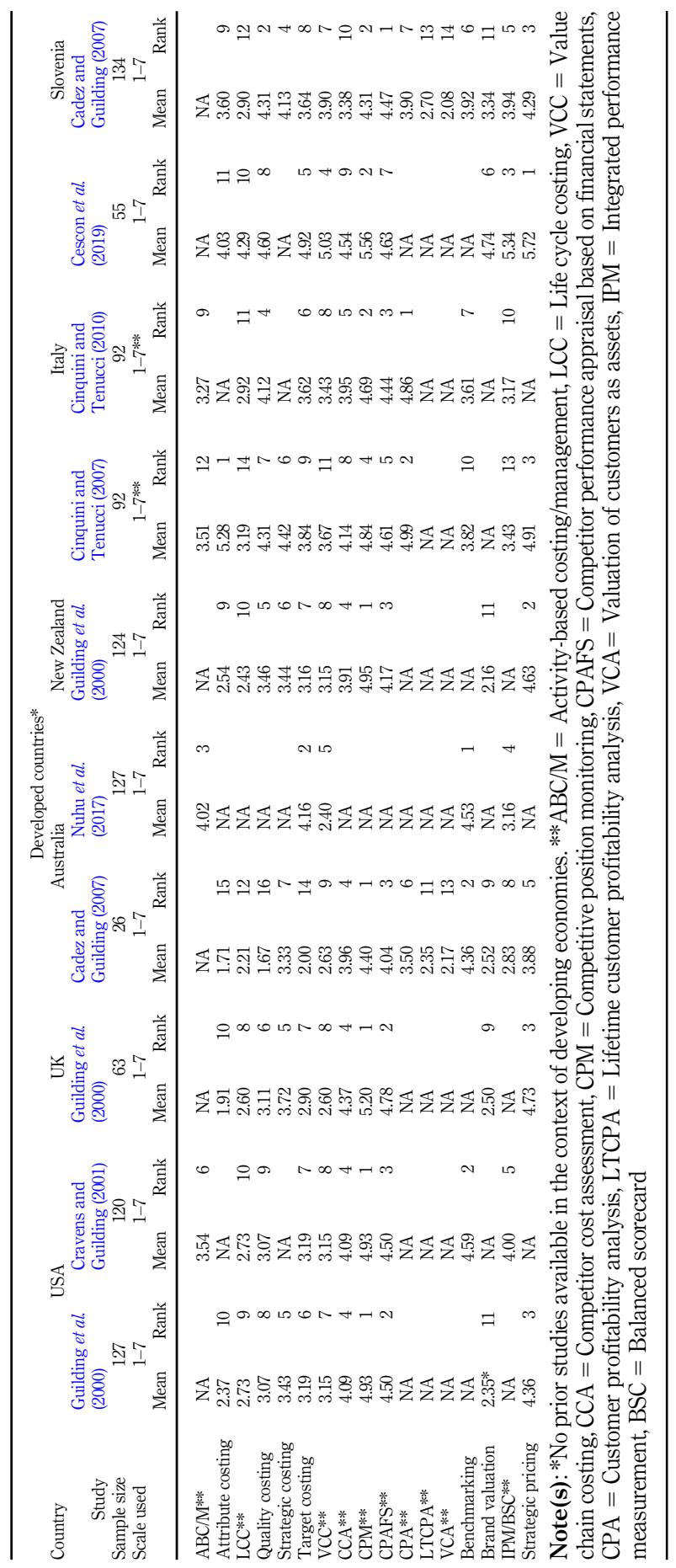

Strategic management accounting practices

113

Table 2. Adoption status of SMA techniques 
AJAR

6,1

114

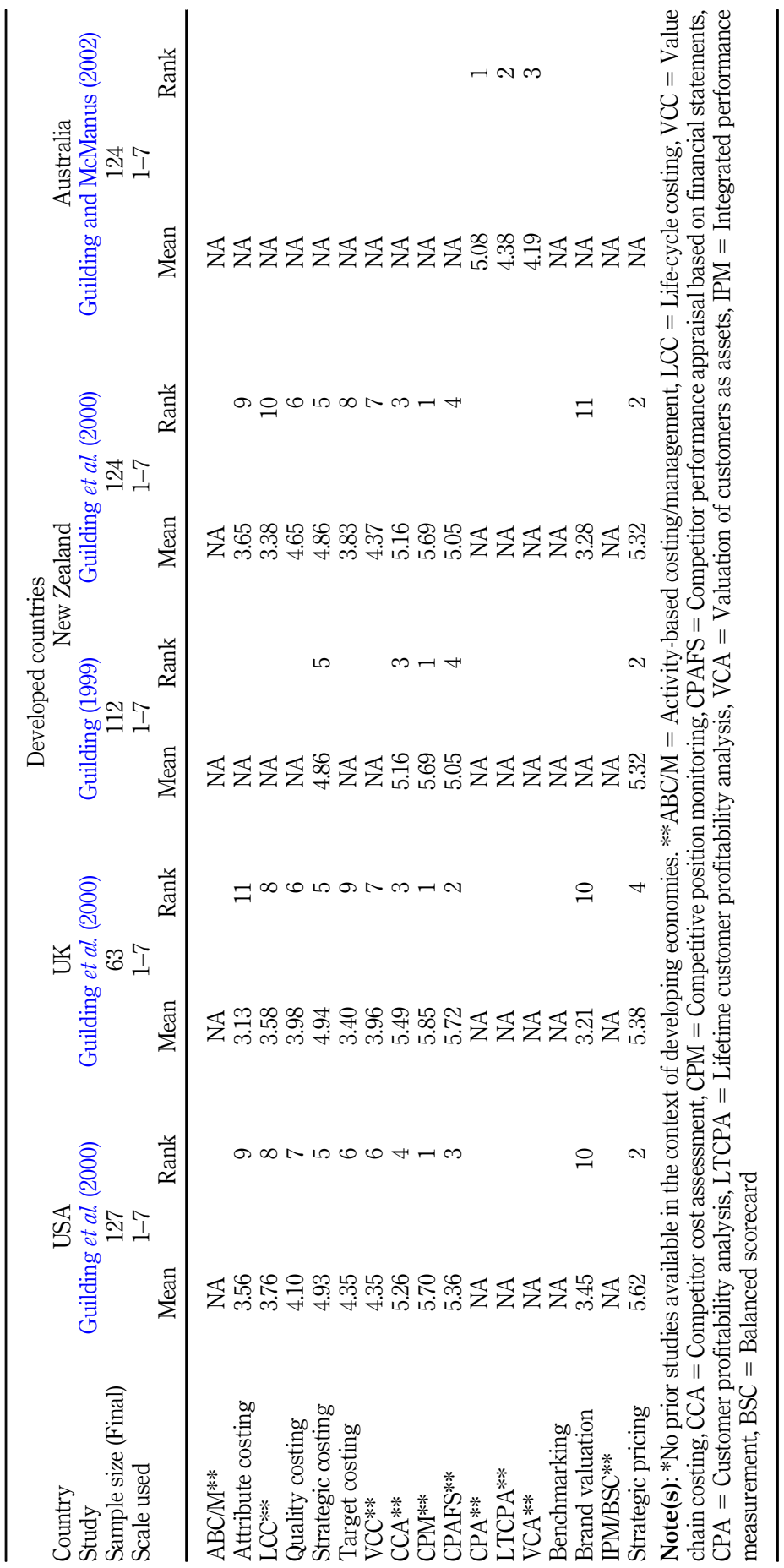

Table 3.

Benefits (perceived) derived from the use of SMA techniques 
accounting", which trimmed down the list to 14 techniques from that of 16 of Cadez and Guilding (2007). Their findings revealed that SMA techniques are extensively used in the sample firms. Attribute costing and customer accounting were found to be the most widely adopted SMA techniques among the sample firms. However, akin to the findings of Guilding et al. (2000), Cravens and Guilding (2001) and Cadez and Guilding (2007), CPM and strategic pricing were also found to be highly adopted by the Italian manufacturing firms.

Cinquini and Tenucci (2010) conducted another survey among the 92 largest Italian manufacturing firms. They excluded three techniques (attribute costing, strategic costing and strategic pricing) from the list of their 2007 study. The remaining 11 SMA techniques were grouped under four different categories (costing, customer, competitor and performance). Consistent with the previous results, this study also documented greater usage of customer accounting, CPM and CPAFS in the Italian manufacturing firms.

Nuhu et al. (2017) surveyed 127 public sector organizations in Australia and documented greater use of benchmarking, target costing and $\mathrm{ABC}$ among the eight SMA techniques studied. Cescon et al. (2019) executed another survey on the use of 11SMA techniques in 55 large Italian manufacturing firms. While the usage rate of CPM (ranked 2nd) was consistent with the findings of Chinquini and Tenucci (2010), the usage rate of VCC (ranked 8th in Chinquini and Tenucci study and 4th in Cescon et al. study) and BSC (ranked 13th in Chinquini and Tenucci study and 3th Cescon et al. study) displayed different level of usage.

The findings of the empirical studies conducted on the adoption and perceived benefits of SMA techniques as a package in the developed countries revealed diversified results. SMA usage in USA, UK, Australia and New Zealand demonstrated comparatively lower usage as compared to Italy and Slovenia. However, competitor-based SMA techniques are found as the most widely used techniques in all the countries. Additionally, benchmarking and strategic pricing are reported as highly used techniques in the USA, UK, Australia and New Zealand, whereas customer accounting is the most popular SMA technique in Italy and Slovenia. More importantly, the above average score on perceived benefits signifies their greater usage in the upcoming days.

3.1.2 In the context of developing economy. Surprisingly, no single study has been conducted (to the best of our knowledge) in the context of developing economy that focused exclusively on the adoption or benefits of SMA techniques (as a package or as a particular group of technique). However, a small number of studies have focused on the adoption of a particular SMA technique. With respect to the rate of adoption, majority of the prior studies revealed low adoption rate. For example, Sartorius et al. (2007) revealed that only $12 \%$ (21 of 181 companies) of the surveyed listed companies in South Africa has adopted ABC in their organizations. Abdul Majid and Sulaiman (2008) also reported that $\mathrm{ABC}$ has not been widely adopted in Malaysian companies.

With respect to the use of BSC, Anand et al. (2005) revealed that $45.28 \%$ of companies in India adopted BSC with greater emphasizes on financial perspective. Khan et al. (2011) conducted a survey among 60 Bangladeshi listed companies and found that only $10 \%$ of the sample companies used BSC in full fledges. Thus, the extant literature failed to expose the picture of the adoption and benefits of SMA techniques as a package in the context of developing economy.

The substantial difference in the extent of adoption and benefits of SMA techniques demonstrated in the foregoing section can be attributed to cultural, legal and institutional factors. Firms in the developed economies are operated in a strong legal and institutional environment where opportunities to conceal income and escape tax is hardly possible and subject to substantial penalty. This motivates firms to pay more attention on formulating strategy to control cost and allocate resources optimally through the extensive use of innovative management and operational tools. In contrast, there exist considerable loopholes in the legal and institutional systems in the developing countries which stimulate firms to
Strategic
management
accounting
practices

115 
AJAR

6,1

devote more time and effort to earning management and tax avoidance activities. Placing extensive weight on compliance issues to manage earnings and tax and overlooking the adoption of innovative and strategic oriented cost management tools by top management team (TMT) becomes the customary practices in the firms in these countries. Moreover, Hopper et al. (2009) argued that excessive dependency for external finance, ideologies and structural reforms; with lower institutional capacity to deliver changes affect a lot the status of MAC system in less developed economies. Accordingly, the use of strategic-oriented SMA techniques appears to be much higher in the developed economies as compared to their counterparts.

\subsection{Factors influencing the adoption decision}

3.2.1 In the context of developed economy. Identical to the scenario of adoption of SMA techniques, majority of the prior studies focusing on the identification of factors contingent to their adoption have been conducted in the context of developed countries. For example, Guilding (1999) identified company size, competitive strategy and strategic mission as the most influential contingent factors affecting the decision to use competitor-focused SMA techniques in New Zealand. In USA, Cravens and Guilding (2001) investigated the effect of eight sub-dimensions of competitive strategy on the adoption of SMA techniques and documented that SMA usage rate is higher in companies pursuing "research and development" and "broad market coverage" strategies (see Table 4).

Guilding and McManus (2002) also employed contingency theory and used the intensity of competition, company size and market orientation as the contingency factors in examining their effect on the use of customer-focused SMA techniques in Australia. Their findings revealed a positive association between different forms of customer accounting techniques and market orientation strategy. Additionally, a positive association between the intensity of competition and customer segment profitability analysis, and customer accounting and company size were also evident. In contrast, Chinquini and Tenucci (2007) documented contrary results in terms of the effect of strategic orientation and reported an insignificant effect of company size, type of industry, strategic pattern and strategic mission on the adoption of SMA techniques in the Italian manufacturing firms.

Cadez and Guilding (2008) employed an integrated contingency model and applied structured equation model to examine the effect of strategic choices, market orientation and company size on SMA usage in the context of Slovenia. The findings revealed that SMA usage is positively associated with adopting prospector strategy, deliberate strategy formulation, company size and accountant's participation in strategic decision-making. Their findings are contradictory with Chinquini and Tenucci (2007) which documented that SMA usage are not strategy driven in the Italian manufacturing firms.

Chinquini and Tenucci (2010) extended their previous study (Chinquini and Tenucci, 2007) and examined the effect of strategy followed and firm size on the adoption of SMA techniques in the largest Italian manufacturing firms. They showed that companies following "defenders" (strategic pattern) and cost leadership (strategic positioning) strategies make greater usage of costing-based SMA techniques, while "build" companies (strategic mission) are intended to use customer-oriented SMA techniques. These findings are not consistent with that of their previous studies conducted in 2007 which revealed weak association between SMA usage and strategy pursued.

Apart from the effect of strategy type on SMA usage, Lachmann et al. (2013) investigated the effect of structural characteristics (size, ownership and legal form) and reported a significant positive effect of several structural characteristics on the usage of SMA techniques in the German hospitals. Nuhu et al. (2017), on the other hand, concentrated their focus on Australian public sector organization and investigated whether the interactive and 


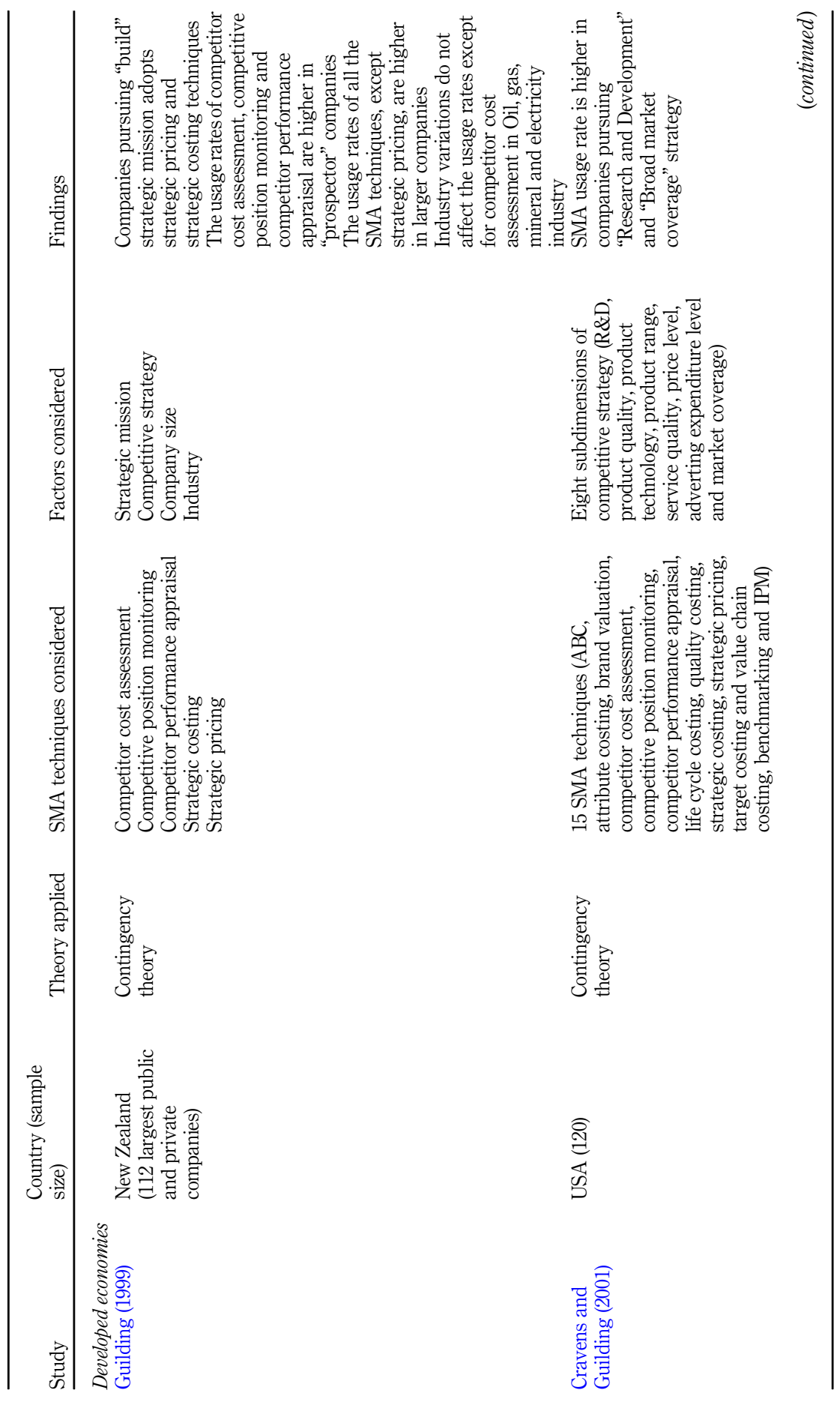

Strategic management accounting practices adoption of SMA techniques 
AJAR
6,1

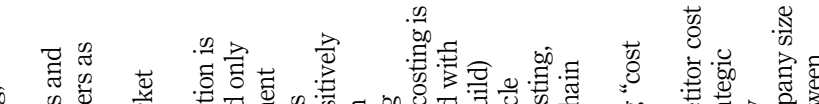

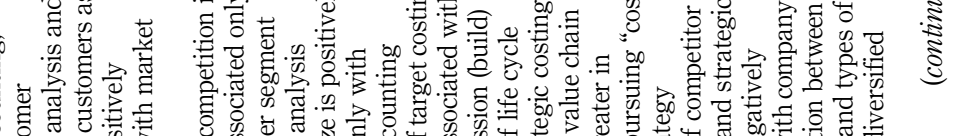

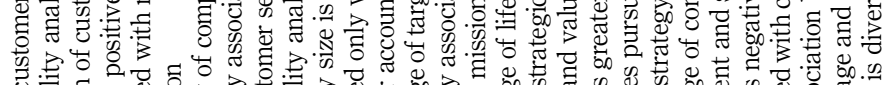

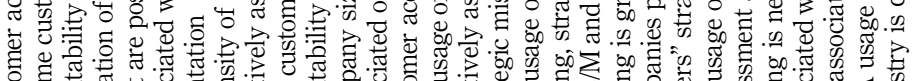

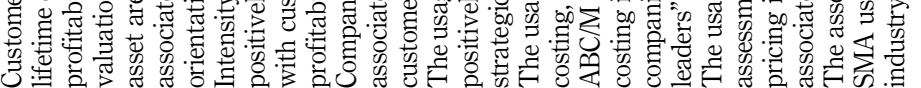

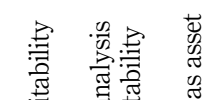

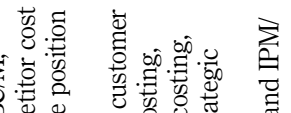

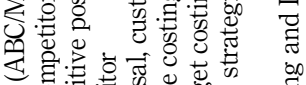

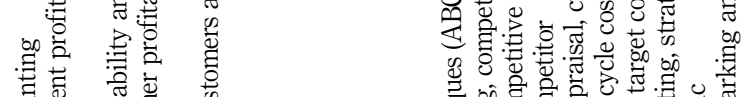
节寻

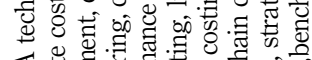

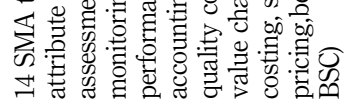

总

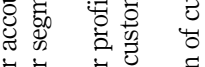

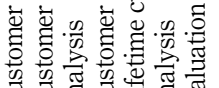

Table 4.

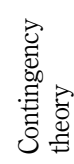

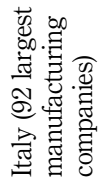

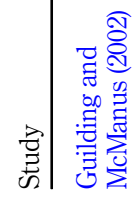

\section{篂㩆}




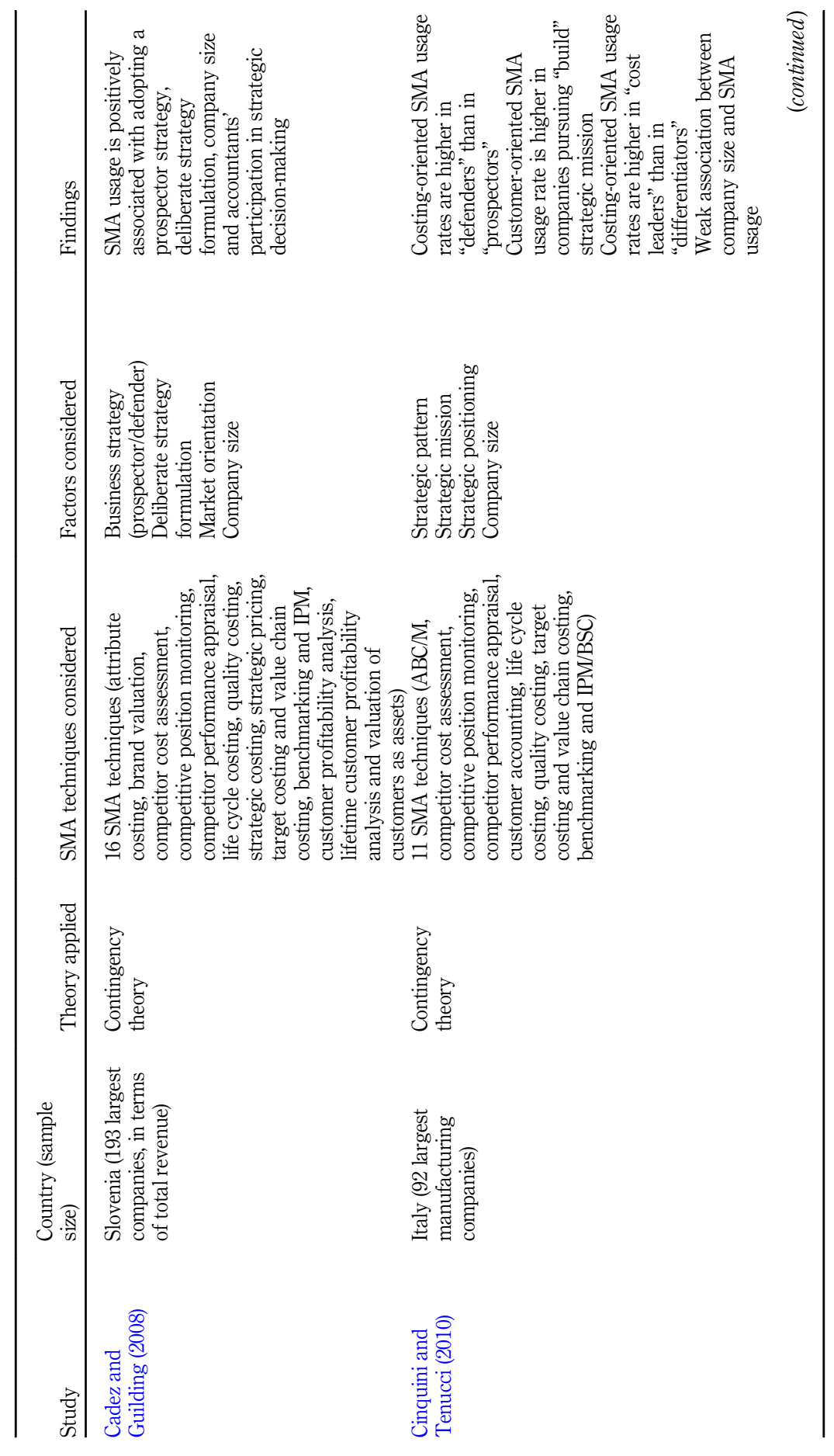

Strategic management accounting practices

119

Table 4. 


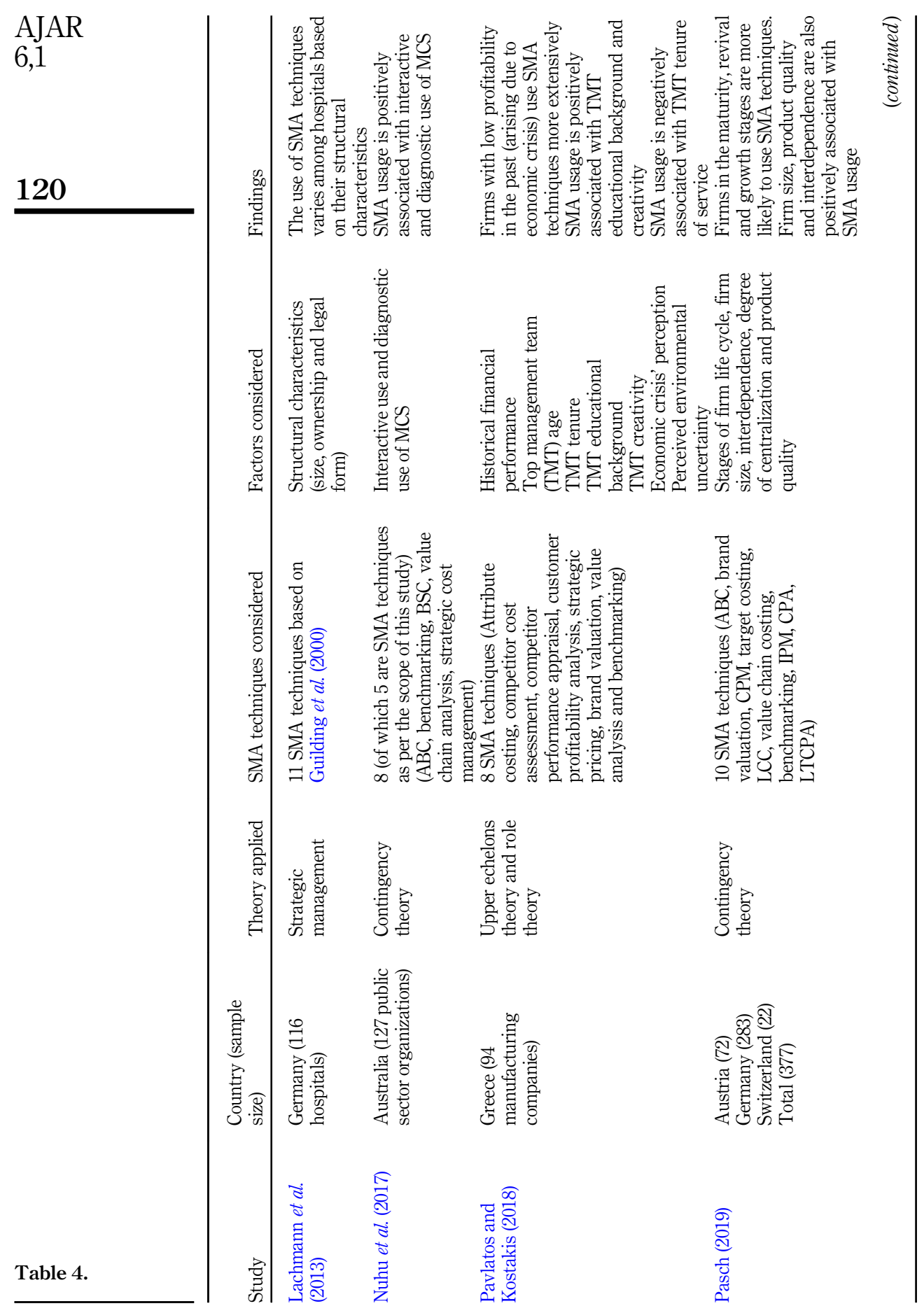




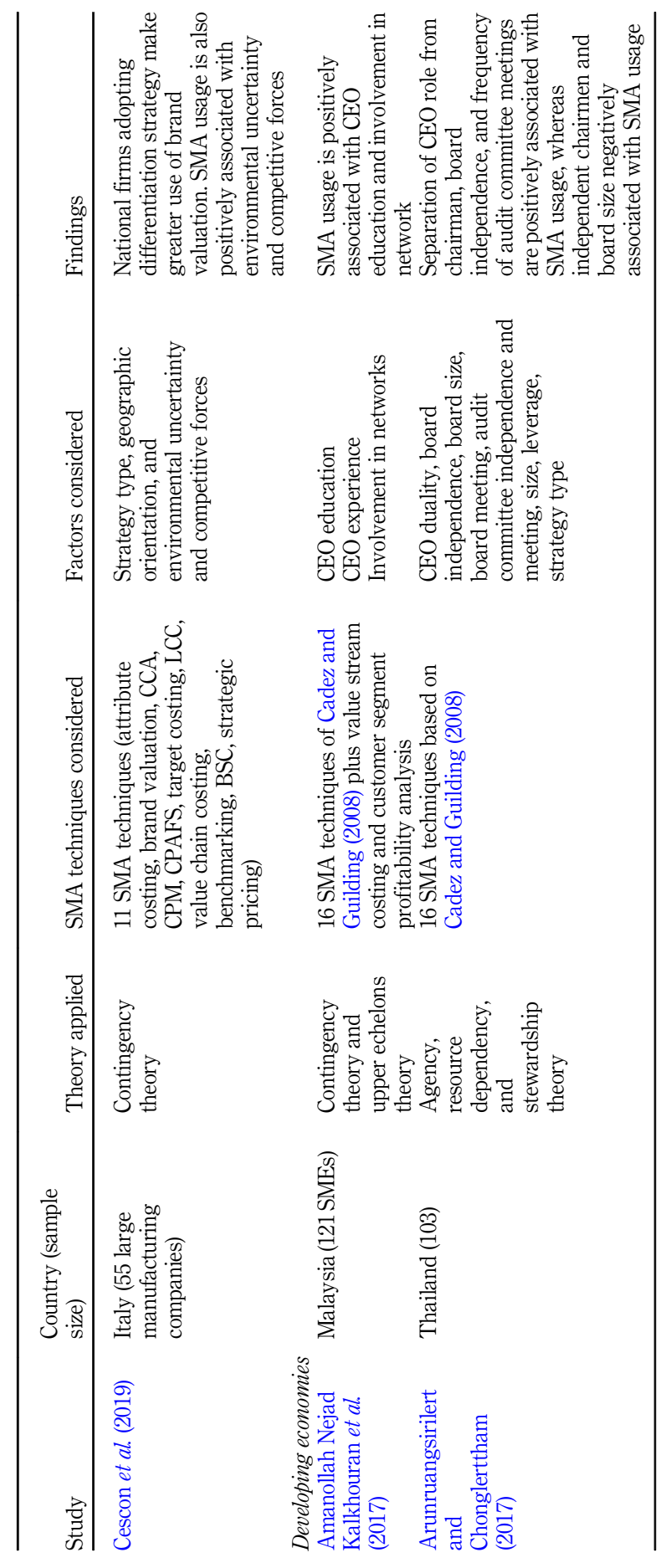


AJAR 6,1

diagnostic use of management control systems (MCS) affect the adoption of SMA techniques. Their findings revealed that SMA usage in the surveyed organizations is positively and significantly affected by the interactive and diagnostic use of MCS.

While majority of the prior studies employed contingency theory in identifying the influential factors, Pavlatos and Kostakis (2018) used upper echelons theory and role theory in examining the effect of TMT characteristics and historical financial performance on the extent of SMA usage in Greek manufacturing companies. The findings revealed that companies that have experienced low profitability in the past adopted and used SMA techniques more extensively to improve performance. With respect to the TMT characteristics, the study showed that educational background, tenure and creativity of TMT were found to be significantly associated with the usage of SMA techniques.

Patch (2019) conducted an international study (Austria, Germany and Switzerland) to investigate the effect of organizational life cycle on the usage of SMA techniques. Their findings revealed a significant positive influence of maturity, revival and growth stages on the SMA usage. Cescon et al. (2019) conducted another study in the Italian manufacturing firm and documented significant positive effect of environmental uncertainty and competitive forces on the adoption of SMA techniques. Their study also documented greater usage of brand valuation in the local firms pursing differentiation strategy.

The findings on the factors influencing the adoption of SMA techniques in the developed economies are rather inconclusive. The effects of several dimension of business strategy adopted appear to be controversial, while the effects of company size, prospector-type strategy, accountants' participation in strategy formulation, TMT education and creativity, and market orientation appears to be mostly positive. The underlying reason for such differences can be attributed to the nature of the context used and techniques applied. The dominance of contingency theory (as depicted in Table 4) is also noticeable which is consistent with the findings of Rashid et al. (2020).

3.2.2 In the context of developing economy. Studies focusing exclusively on the identification of influential factors in the context of developing countries are apparently low. We found only two studies that have addressed the issue. Amanollah Nejad Kalkhouran et al. (2017) surveyed 1,000 small and medium-sized enterprises (SMEs) in Malaysia (121 useable responses were received) to examine the effect of CEO characteristics (represented by education and experience) and their involvement in networks on SMA usage. The study employed contingency theory and upper echelons theory in examining the hypothesized relationships. A significant positive effect of $\mathrm{CEO}$ education and involvement in networks on SMA usage was documented by the study.

In the same year, Arunruangsirilert and Chonglerttham (2017) conducted another study to investigate the influence of corporate governance $(\mathrm{CG})$ characteristics on SMA practices in the Thai listed firms. Employing the arguments of agency, resource dependency and stewardship theory, they reported a significant positive influence of several CG characteristics (separations of CEO role from chairman, board independence and frequency of audit committee meetings) on the level of SMA usage. However, the effect of board size and board chairman from outsider was significantly negative on the extent of SMA usage.

Identical to the scenario of adoption status, the factors contingent to the adoption of SMA techniques in firms in the developing economies remained unexplored with few exceptions. More importantly, the contingent factors considered in the studies conducted in the context of developed economies are not studied in the extant literature of developing countries. This can be attributed to the apparently low adoption rate of SMA techniques which stimulate researchers not to devote efforts in exploring the effect of those factors. Nevertheless, the positive effects of CEO education and involvement in networks, and proportion of board independence and separation of CEO role from chairmen on the adoption of SMA techniques have been evident in the developing countries. 
3.3.1 In the context of developed economy. Studies exploring the effect of SMA usage on firm's performance are extremely rare in the context of both developed and developing economies. Cadez and Guilding (2008) applied structured equation model to examine the mediating effect of SMA usage and accountant's participation in strategic decision-making process on firm's performance. Strategy type, market orientation and company size were used as the dependent variables, whereas perceived firm performance was used as the independent variable. The findings revealed a significant positive association between SMA usage and firm's performance (see Table 5).

Four years later, Cadez and Guilding (2012) conducted another survey among the largest manufacturing companies in Slovenia using the configuration approach to examine the relationship between strategy, SMA and performance. The findings revealed that different strategic and structural alternatives can lead to similar performance level. However, only limited support is confirmed with respect to the Configurational proposition that internally consistent configurations can provide better performance.

One year later, Aykan and Aksoylu (2013) examined the effect of SMA usage on perceived qualitative and quantitative performance in 229 Turkish large- and medium-sized firms. Using the premise of strategic management theory, they documented a significant positive influence of competitor-and customer-focused SMA techniques on the perceived qualitative performance. In a later study, Turner et al. (2017) used the contingency theory premise in investigating the mediating effect of SMA usage on the performance of 95 hotel properties in the USA. Hotel property performance was measured using two measurers: customer performance and financial performance. Their findings confirmed a mediating role of SMA usage between hotel property market orientation business strategy and hotel property financial performance.

3.3.2 In the context of developing economy. To a very limited extent, the effects of SMA usage on firm's performance have been addressed in the context of developing economy. Amanollah Nejad Kalkhouran et al. (2017) examined the indirect effect of SMA usage on firm performance using the context of Malaysia. The study confirmed the mediating effect of SMA usage on firm's performance through CEO education and involvement in networks. Alamri (2019) conducted a survey among 435 accounting managers working in Saudi listed companies with respect to the effect of SMA practices on organizational performance. The study developed five facets of SMA practices in analyzing their effects on both financial and nonfinancial firm's performance. The findings revealed that SMA facets significantly (and positively) affect both financial and nonfinancial performance.

The above discussion revealed that the effects of adopting SMA techniques as a package on several aspects of firm performance have not been well addressed in the extant SMA literature in the context of both developed and developing economies. More specifically, the direct and indirect effect of adopting SMA techniques on accounting-based performance such return on assets (ROA) and return on equity (ROE), and market-based performance such as market-tobook ratio and Tobin's $Q$ ratio remained unexplored in the context of both set of economies.

\section{Summary and future research opportunities \\ 4.1 Summary of the findings}

The review of extant literature on SMA practices revealed several critical facts. First, the volume of studies focusing on the adoption, factors influencing the adoption and the effect of adoption of SMA techniques on firm performance is considerably low. We found only 19 articles (Table 1) published between 1981 and 2019 (both years inclusive), of which only seven articles focused on the extent of adoption (Table 2), three articles on perceived benefits (Table 3), 13 articles on contingent factor (Table 4) and only six articles (Table 5) on the effect of adoption on firm performance. Second, the adoption rate of SMA techniques in majority of the countries is comparatively low, with few exceptions. Surprisingly, the adoption status of SMA techniques

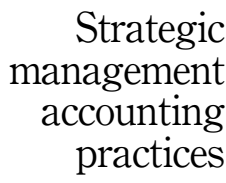

123 


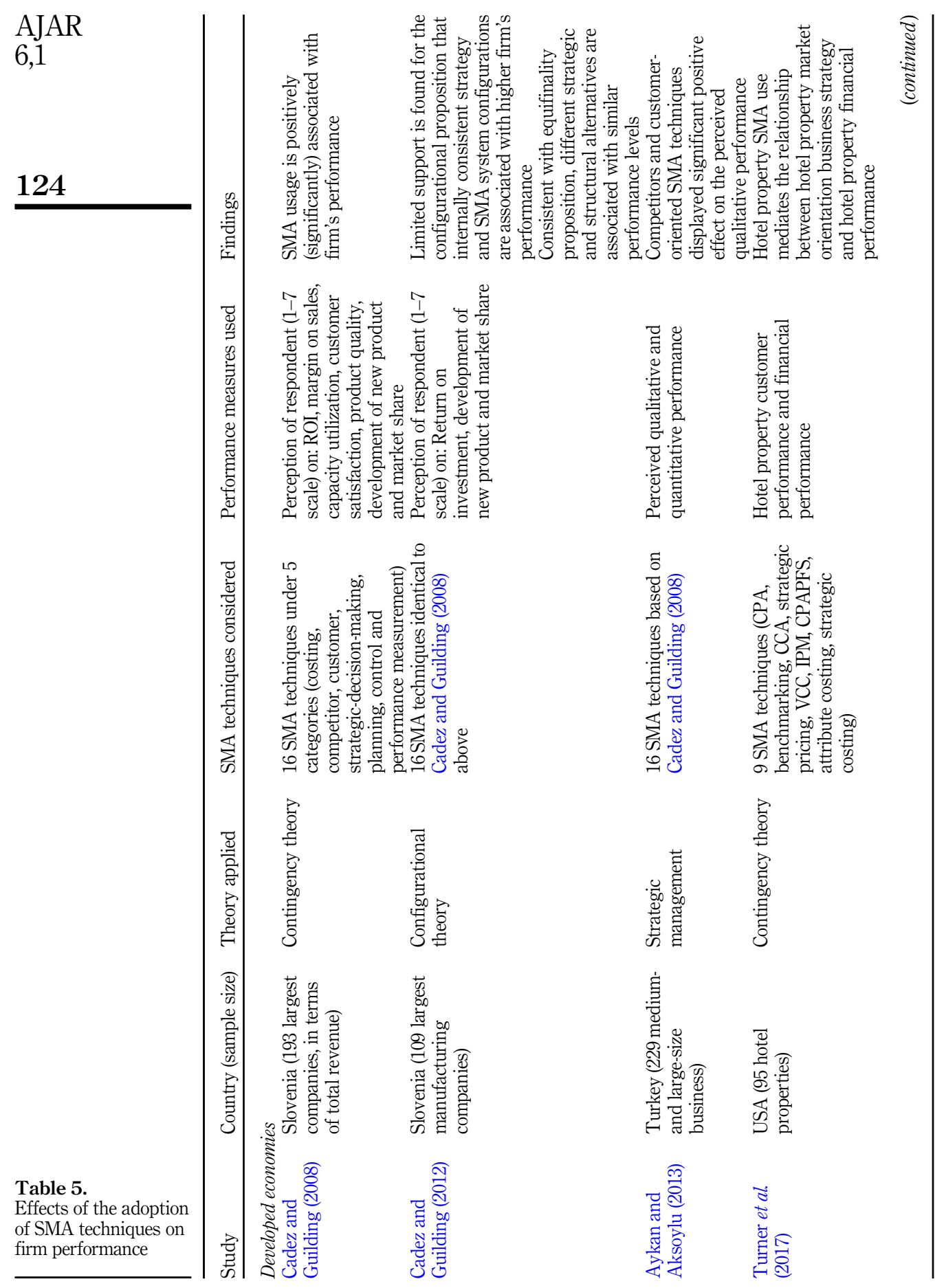




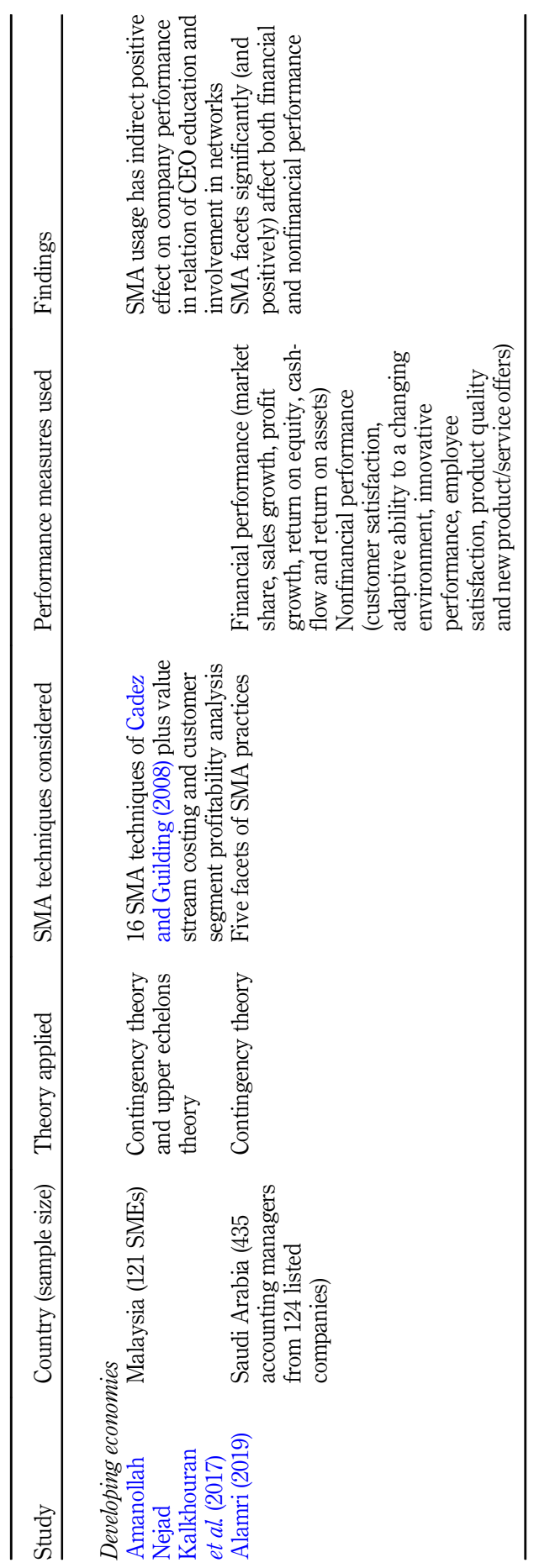

Strategic management accounting practices

125

Table 5. 
AJAR

6,1

126

remained unexplored in the context of developing countries. Third, among the studied SMA techniques, competitor-based accounting techniques were the most widely used in all the countries, with high and moderate use of benchmarking, strategic pricing and customer accounting in specific countries (see Table 6).

Fourth, among the influencing factors studied, strategic positioning (Cinquini and Tenucci, 2007), prospector type strategy, deliberate strategy formulation, company size, accountant's participation in strategic decision-making (Cadez and Guilding, 2008), strategic pattern (Chinquini and Tenucci, 2010), educational background, tenure and creativity of TMT (Pavlatos and Kostakis, 2018), structural characteristics (Lachmann et al., 2013), the use of MCS (Nuhu et al., 2017), the firm's life cycle stages (Pasch, 2019) and the environmental uncertainty, competitive forces and the location of firm (Cescon et al., 2019) were reported as the most influential factors in the adoption decision of SMA techniques. And finally, with respect to the effect of adoption of SMA techniques, a positive direct (Aykan and Aksoylu, 2013; Alamri, 2019) and indirect or mediating effect (Cadez and Guilding, 2008; Amanollah Nejad Kalkhouran et al., 2017; Turner et al., 2017) on several aspects of firm performance have been evident in the context of developed and developing economies.

\begin{tabular}{|c|c|c|}
\hline $\begin{array}{l}\text { Issues of SMA } \\
\text { practices }\end{array}$ & Developed economies & Developing economies \\
\hline $\begin{array}{l}\text { Adoption } \\
\text { status }\end{array}$ & $\begin{array}{l}\text { Competitor-focused SMA techniques and } \\
\text { strategic pricing have been highly and } \\
\text { moderately adopted in most of the developed } \\
\text { countries (e.g. USA, UK, Australia and New } \\
\text { Zealand) } \\
\text { Benchmarking is highly adopted in USA and } \\
\text { Australia }\end{array}$ & $\begin{array}{l}\text { No prior studies have focused on the } \\
\text { adoption status of SMA practices (as a } \\
\text { package) in the context of developing } \\
\text { countries } \\
\text { ABC, BSC and target costing have been } \\
\text { moderately and lowly adopted in several } \\
\text { developing countries }\end{array}$ \\
\hline
\end{tabular}

Perceived $\quad$ Competitive position monitoring, strategic benefits pricing and competitor performance appraisal are perceived highly beneficial by the adopting companies

Several customer-oriented SMA practices are also perceived beneficial to Australian companies

Influencing Strategic mission, positioning and pattern factors have mixed effect on SMA usage; positive association between SMA usage and "build", "prospector" and "cost leader" strategy followers are more apparent R\&D, broad market coverage strategy and deliberate strategy formulation are also positively associated with SMA usage The effect of firm size and industry on SMA usage is mixed with mostly positive in nature Market orientation and intensity of competition, TMT education and creativity also have positive influence on SMA usage

Effects of SMA Positive association between SMA usage and

Table 6. usage firm's performance
Akin to the adoption status, no prior studies have focused on the perceived benefits from the use of SMA practices (as a package) in the context of developing countries

Positive association between SMA usage and CEO education and involvement in network

Positive effect of SMA usage on firm's performance in relation to $\mathrm{CEO}$ education and network is apparent 


\subsection{Future research opportunities}

Surprisingly, the nature and extent of the use of SMA techniques in the face of Fourth Industrial Revolution (IR 4.0) and global climate change remain unexplored in the context of both developed and developing economies. Moreover, the role of management accountant (or strategic management accountant) as a business partner or in the face of changed business model also remain unexplored. Accordingly, with respect to the future research in this field, we suggest researchers to look at the following areas.

4.2.1 SMA in the fourth industrial revolution. The Fourth Industrial Revolution that has been underway over the past half a century (Kotler et al., 2017) has brought exponential changes to the way we live, work and relate to one another due to the adoption of smart technologies in our factories and workplaces (Marr, 2018). More specifically, the Internet and related information technologies (e.g. cloud services, big data, blockchain, AI), combined with web-based business models are rapidly transforming the digital economy and industry (Moll and Yigitbasioglu, 2019). These technological advancement and disruption have also led substantial changes in the underlying infrastructure of management accounting and control practices (MACPS) (Heinzelmann, 2019). In particular, how the innovative MAC techniques (such as SMA) can be used in the changed business situations may be of particular interest to the MAC researchers. Initially, case study of large and multinational enterprises adopting several of these techniques can provide useful insights on the role of management accountants in the context of developing economy. However, in the developed economy where the use of big data, AI, blockchain, cloud computing already received considerable momentum, both case study and survey research can provide more profound picture of SMA practices, specifically researching what affect their adoption, implementation and effect of implementation in the technology-driven environment can be of particular importance.

4.2.1.1 Cloud computing. Cloud-based solutions are used in a range of accounting functions; including analytics, control reporting, monitoring and data governance (Heinzelmann, 2019; Moll and Yigitbasioglu, 2019). Of the four possible cloud deployment models (private, public, community and hybrid cloud), public cloud has received the vast attention of firms. In the field of MAC, cloud-based solutions are beneficial to improve planning and control via enhanced forecasting and benchmarking functionalities (Heinzelmann, 2019), and provide real-time access to data from any (mobile) device (Moll and Yigitbasioglu, 2019). However, empirical evidence on the utility of cloud-based solutions in a real-life setting remains limited (Heinzelmann, 2019; Moll and Yigitbasioglu, 2019), and therefore future research may focus on this issue, specifically how SMA techniques are being applied in cloud-based solutions environment.

4.2.1.2 Big data. Big data, arising from a wider configuration of information pools (past and present, structured and unstructured, social and economic, formal and informal), poses challenges to enterprises, multiplies the potential organizational data engagement and shape the firm's strategy processes (Bhimani, 2015). Big data is used in combination with established data sources to improve managerial decisions and actions (Bhimani, 2015), and have substantial impact on MACPS (Bhimani and Willcocks, 2014). Big data and analytics may be beneficial (Bhimani, 2015) if they can be organized and used in a meaningful way to helps organizations make better decision which requires management accountant to have business insights and data skills (Heinzelmann, 2019). Accordingly, future research may focus on how the use of innovative SMA techniques is allied in the big data environment. Specifically, the case study research may portray the changing role and skills required for management accountants in such environment in developing countries, while both case study and survey research in the context of developed economy may convey what factors affect the adoption, implementation and effect of SMA in big data environment.

4.2.1.3 Blockchain. Blockchain is a type of distributed ledger technology where the members (known as "nodes") of a large network share multiple copies of the same ledger (Moll

\section{management accounting practices}

Strategic 
AJAR 6,1 and Yigitbasioglu, 2019). It involves triple entry bookkeeping in which every transaction requires three entries to record a debit, a credit and a cryptographic signature to check the validity of a transaction (Heinzelmann, 2019; Moll and Yigitbasioglu, 2019). The core advantage of this technology is that once a transaction is approved by the nodes in the network, it cannot be reversed or resequenced, which, in turn, ensures the transparency of the transactions and any change to it to all the members of that network (Moll and Yigitbasioglu, 2019). The impact of blockchain on accounting profession is obvious specifically for the design of accounting information system, audit and assurance (Brandon, 2016; Moll and Yigitbasioglu, 2019). However, its impact on MACPS is not clear yet (Heinzelmann, 2019), and accordingly future research may focus on the changing role of management accountant in firm (using case study approach) implementing or implemented blockchain technology.

4.2.1.4 Artificial intelligence (AI). AI includes innovations (e.g. machine learning and natural language processing), as well as statistical techniques in which the system learns by example without any human intervention (Moll and Yigitbasioglu, 2019). In MAC, it seems that despite having a broader understanding of $\mathrm{AI}$, skills required to address AI requirements to add value to work in this area are still inadequate (Krumwiede, 2017; Moll and Yigitbasioglu, 2019). Future research should investigate the business value of $\mathrm{AI}$ in terms of better decision-making, control and organizational performance (Moll and Yigitbasioglu, 2019). Explorative studies may help uncover improvements in MACPS in general, and SMA in particular, to the adoption of AI.

4.2.2 Role of management accountant as business partner. The notion of "business partner" is seen as a popular template for practicing management accountants (Rieg, 2018) and refers to more than the tasks of scorekeeping and delivering aggregated financial information to top management (Karlsson et al., 2019). To hold the status in true sense, management accountant have to move beyond traditional MAC functions and have to become a capable provider of rich, forward-looking information for strategic decisions (Granlund and Lukka, 1998; Karlsson et al., 2019). Granlund and Lukka (1998) and Karlsson et al. (2019) provided evidence in support of hybrid accountant whereby management accountant performs the role of traditional scorekeeping tasks with some business partner characteristics. Future research may focus on how the implementation of SMA techniques (as a package or a specific technique) assists management accountants to step forward the role of a business partner.

4.2.3 SMA in the new business model. Business models denote the underlying structures of how companies create, deliver and capture value (Clinton and Whisnant, 2019). The embeddedness of digital technologies (e.g. Internet of things) stimulates many firms to change their business models (Bouwman et al., 2017) to adapt to their environment (Rachinger et al., 2019). The influence of this digitalization on business model seems to be fuzzy and challenging (Bouwman et al., 2017), and people are uncertain about how to face the rapid technological change, changing customer preferences and legal requirements, and how to capitalize the new technological opportunities (Lerch and Gotsch, 2015; Rachinger et al., 2019). Future research (exploratory) may focus on how the application of innovative SMA techniques in a particular organization assists in achieving competitive advantage in the changed business model.

4.2.4 SMA in addressing climate change. Greenhouse gas (GHG) emissions are considered as the major cause of global climate change (Karl and Trenberth, 2003; Cadez et al., 2019), and accordingly GHG-intensive firms from the energy and industry sectors are found to be the major contributors in this respect (Cadez and Czerny, 2016). Despite the notable corporate action to control the GHG emission worldwide, the volume of GHG emissions from those sectors continue to rise globally (Cadez et al., 2019). Future research may focus on this issue by exploring how management accountant respond to control GHG emission through including the environmental costs of emissions to a number of innovative MAC (specifically SMA) techniques. Case study research seems to be more appealing in addressing the issue in energy and industry sector firms. 


\section{Conclusion}

The aim of this paper was to present a review of literature between 1981 and 2019 (both years inclusive) on the adoption status, benefits, factors influencing to the adoption of SMA techniques and their effects on firm performance in the context of developed and developing economies. The findings revealed a low volume (only 19 papers) of articles published on the subject during the period. Majority of the 17 SMA techniques studied experienced a low adoption rate with few exceptions where competitor- and customer-focused techniques, strategic pricing and benchmarking are moderately and highly adopted in several developed countries. This finding implies that SMA techniques could not replace the traditional MAPs; rather they are used as complementary tools to traditional MAPs. However, we are in the dark with respect to the status of SMA practices in the developing economies. The effects of several contingent factors (e.g. type of strategy adopted, company size) are rather controversial and inconclusive. However, despite the low volume of papers published and variables studied, a significant positive effect SMA usage on several aspects of firm performance is obvious in the context of both developed and developing economies.

The findings of the present review can have implications from a theoretical, policymaking and practitioner perspectives. From a theoretical perspective, the dominance of using "contingency theory" in identifying the factors influencing the adoption decision signifies the acceptability of this theory in the empirical-based SMA research. Additionally, the arguments of other theories such as upper echelons theory, role theory, agency theory and stewardship theory are also complementary with the findings of few studies. From the policymakers' perspective, the significant positive influence of SMA adoption on firm performance documented by several studies urges the need for policies that would induce firms to adopt and implement innovative MAC (SMA) techniques. Specifically, policymakers in developing economies have to initiate measures to change the focus of corporations from earnings management and tax avoidance to the attainment of competitive advantages through adopting and exercising innovative management and operational tools. From practitioners view, top management may take initiative to introduce strategic-oriented MAC techniques in organizations to improve efficiency in resource allocation and to facilitate more accurate and timely strategic decision.

The present study has some limitations. First, there exist variations in terms of sample size, firm size and measurement scale of extent of adoption among several studies that are compared. Therefore, the results must be interpreted considering such limitations. Second, most of the studies considered in the paper are based on questionnaire survey. We did not consider studies based on other methods as they rarely focused on the adoption or effect of adoption of SMA techniques. Finally, the study considered a list of 17 SMA techniques based on prior studies. As there exists no universally agreed definition of SMA and its conceptual framework (Tomkins and Carr, 1996; Langfield-Smith, 2008), the list of SMA techniques considered are bound to be subjective (Cadez and Guilding, 2007).

Despite these limitations, the review of extant literature and future research opportunities presented above are expected to contribute to the development of future SMA research.

\section{Note}

1. The study uses the World Factbook (of Central Intelligence Agency) to isolate developed countries from that of developing countries (The World Factbook, 2020).

\section{References}

Abdul Majid, J. and Sulaiman, M. (2008), "Implementation of activity based costing in Malaysia: a case study of two companies", Asian Review of Accounting, Vol. 16 No. 1, pp. 39-55.

Alamri, A.M. (2019), "Association between strategic management accounting facets and organizational performance”, Baltic Journal of Management, Vol. 14 No. 2, pp. 212-234.

\section{management accounting practices}

Strategic 
AJAR

6,1

Amanollah Nejad Kalkhouran, A., Hossein Nezhad Nedaei, B. and Abdul Rasid, S.Z. (2017), "The indirect effect of strategic management accounting in the relationship between CEO characteristics and their networking activities, and company performance", Journal of Accounting and Organizational Change, Vol. 13 No. 4, pp. 471-491.

Anand, M., Sahay, B.S. and Saha, S. (2005), "Activity-based cost management practices in India: an empirical study”, Decision, Vol. 32 No. 1, pp. 123-152.

Arunruangsirilert, T. and Chonglerttham, S. (2017), "Effect of corporate governance characteristics on strategic management accounting in Thailand", Asian Review of Accounting, Vol. 25 No. 1, pp. 85-105.

Ashton, D., Hopper, T. and Scapens, R. (1995), "The changing nature of issues in management accounting", in Ashton, D., Hopper, T. and Scapens, R. (Eds), Issues in Management Accounting, Prentice Hall, Hertfordshire.

Aykan, E. and Aksoylu, S. (2013), "Effects of competitive strategies and strategic management accounting techniques on perceived performance of businesses", Australian Journal of Business and Management Research, Vol. 3 No. 7, pp. 30-39.

Bhimani, A. (2015), "Exploring big data's strategic consequences", Journal of Information Technology, Vol. 30 No. 1, pp. 66-69.

Bhimani, A. and Willcocks, L. (2014), 'Digitisation, 'big data' and the transformation of accounting information", Accounting and Business Research, Vol. 44 No. 4, pp. 469-490.

Bouwman, H., de Reuver, M. and Shahrokh, N. (2017), "The impact of digitalization on business models: how IT artefacts, social media, and big data force firms to innovate their business model", 14th International Telecommunications Society (ITS) Asia-Pacific Regional Conference, Kyoto, June 24-27.

Brandon, D. (2016), "The blockchain: the future of business information systems", International Journal of the Academic Business World, Vol. 10 No. 2, pp. 33-40.

Cadez, S. and Czerny, A. (2016), "Climate change mitigation strategies in carbon-intensive firms", Journal of Cleaner Production, Vol. 112, pp. 4132-4143.

Cadez, S. and Guilding, C. (2007), "Benchmarking the incidence of strategic management accounting in Slovenia”, Journal of Accounting and Organizational Change, Vol. 3 No. 2, pp. 126-146.

Cadez, S. and Guilding, C. (2008), "An exploratory investigation of an integrated contingency model of strategic management accounting”, Accounting, Organizations and Society, Vol. 33 Nos 7-8, pp. 836-863.

Cadez, S. and Guilding, C. (2012), "Strategy, strategic management accounting and performance: a configurational analysis", Industrial Management and Data Systems, Vol. 112 No. 3, pp. 484-501.

Cadez, S., Czerny, A. and Letmathe, P. (2019), "Stakeholder pressures and corporate climate change mitigation strategies", Business Strategy and the Environment, Vol. 28 No. 1, pp. 1-14.

Cescon, F., Costantini, A. and Grassetti, L. (2019), "Strategic choices and strategic management accounting in large manufacturing firms", Journal of Management and Governance, Vol. 23 No. 3, pp. 605-636.

Cinquini, L. and Tenucci, A. (2007), "Is the adoption of strategic management accounting techniques really 'strategy-driven'? Evidence from a survey”, available at: https://mpra.ub.uni-muenchen. de/11819/1/MPRA_paper_11819.pdf (accessed 5 October 2018).

Cinquini, L. and Tenucci, A. (2010), "Strategic management accounting and business strategy: a loose coupling?”, Journal of Accounting and Organizational Change, Vol. 6 No. 2, pp. 228-259.

Clinton, L. and Whisnant, R. (2019), "Business model innovations for sustainability", Managing Sustainable Business, Springer, Dordrecht, pp. 463-503.

Coad, A. (1996), "Smart work and hard work: explicating a learning orientation in strategic management accounting", Management Accounting Research, Vol. 7 No. 4, pp. 387-408. 
Cravens, K.S. and Guilding, C. (2001), "An empirical study of the application of strategic management accounting techniques", Advances in Management Accounting, Vol. 10, pp. 95-124.

Granlund, M. and Lukka, K. (1998), "Towards increasing business orientation: Finnish management accountants in a changing cultural context", Management Accounting Research, Vol. 9 No. 2, pp. 185-211.

Guilding, C. (1999), “Competitor-focused accounting: an exploratory note”, Accounting, Organizations and Society, Vol. 24 No. 7, pp. 583-595.

Guilding, C. and McManus, L. (2002), "The incidence, perceived merit and antecedents of customer accounting: an exploratory note", Accounting, Organizations and Society, Vol. 27 Nos 1-2, pp. 45-59.

Guilding, C., Cravens, K.S. and Tayles, M. (2000), "An international comparison of strategic management accounting practices", Management Accounting Research, Vol. 11 No. 1, pp. 113-135.

Heinzelmann, R. (2019), "Digitalizing management accounting”, Controlling-Aktuelle Entwicklungen und Herausforderungen, Springer Gabler, Wiesbaden, pp. 207-226.

Hopper, T., Tsamenyi, M., Uddin, S. and Wickramasinghe, D. (2009), "Management accounting in less developed countries: what is known and needs knowing", Accounting, Auditing and Accountability Journal, Vol. 22 No. 3, pp. 469-514.

Johnson, H. and Kaplan, R. (1987), Relevance Lost: The Rise and Fall of Management Accounting, Harvard Business School Press, Boston.

Kaplan, R.S. (1984), "Yesterdays accounting undermines production", Harvard Business Review, Vol. 62 No. 4, pp. 95-101.

Karl, T.R. and Trenberth, K.E. (2003), "Modern global climate change", Science, Vol. 302 No. 5651, pp. 1719-1723.

Karlsson, B., Hersinger, A. and Kurkkio, M. (2019), "Hybrid accountants in the age of the business partner: exploring institutional drivers in a mining company", Journal of Management Control, Vol. 30 No. 2, pp. 185-211.

Khan, H.U.Z., Halabi, A.K. and Sartorius, K. (2011), "The use of multiple performance measures and the balanced scorecard (BSC) in Bangladeshi firms: an empirical investigation", Journal of Accounting in Emerging Economies, Vol. 1 No. 2, pp. 160-190.

Kotler, P., Kartajaya, H. and Huan, H.D. (2017), Marketing for Competitiveness: Asia to the World! in the Age of Digital Consumers, World Scientific, Singapore.

Krumwiede, K. (2017), "How to keep your job”, available at: https://sfmagazine.com/technotes/ september-2017-how-to-keep-your-job/ (accessed 1 March 2020).

Lachmann, M., Knauer, T. and Trapp, R. (2013), "Strategic management accounting practices in hospitals: empirical evidence on their dissemination under competitive market environments", Journal of Accounting and Organizational Change, Vol. 9 No. 3, pp. 336-369.

Langfield-Smith, K. (2008), "Strategic management accounting: how far have we come in 25 years?", Accounting, Auditing and Accountability Journal, Vol. 21 No. 2, pp. 204-228.

Lerch, C. and Gotsch, M. (2015), "Digitalized product-service systems in manufacturing firms: a case study analysis", Research-Technology Management, Vol. 58 No. 5, pp. 45-52.

Marr, B. (2018), "The 4th industrial revolution is here - are you ready?", available at: https:/www. forbes.com/sites/bernardmarr/2018/08/13/the-4th-industrial-revolution-is-here-are-you-ready/ \#40c624cf628b (accessed 29 February 2020).

Moll, J. and Yigitbasioglu, O. (2019), "The role of internet-related technologies in shaping the work of accountants: new directions for accounting research", The British Accounting Review, Vol. 51 No. 6, 100833, doi: 10.1016/j.bar.2019.04.002.

Nuhu, N., Baird, K. and Bala Appuhamilage, A. (2017), "The adoption and success of contemporary management accounting practices in the public sector", Asian Review of Accounting, Vol. 25 No. 1, pp. 106-126.

\section{management accounting practices}

Strategic 
AJAR

6,1

Pasch, T. (2019), "Organizational lifecycle and strategic management accounting", Journal of Accounting and Organizational Change, Vol. 15 No. 4, pp. 580-604.

Pavlatos, O. and Kostakis, X. (2018), "The impact of top management team characteristics and historical financial performance on strategic management accounting", Journal of Accounting and Organizational Change, Vol. 14 No. 4, pp. 455-472.

Rachinger, M., Rauter, R., Müller, C., Vorraber, W. and Schirgi, E. (2019), "Digitalization and its influence on business model innovation", Journal of Manufacturing Technology Management, Vol. 30 No. 8, pp. 1143-1160.

Rashid, M.M., Ali, M.M. and Hossain, D.M. (2020), "Revisiting the relevance of strategic management accounting research", PSU Research Review, Vol. 4 No. 2, pp. 129-148.

Rieg, R. (2018), "Tasks, interaction and role perception of management accountants: evidence from Germany", Journal of Management Control, Vol. 29 No. 2, pp. 183-220.

Sartorius, K., Eitzen, C. and Kamala, P. (2007), "The design and implementation of activity based costing (ABC): a South African survey", Meditari Accountancy Research, Vol. 15 No. 2, pp. 1-21.

Shields, M.D. (1997), "Research in management accounting by North Americans in the 1990s", Journal of Management Accounting Research, Vol. 9, pp. 3-61.

Simmonds, K. (1981), "Strategic management accounting”, Management Accounting, Vol. 59, pp. 9-26.

The World Factbook (2020), The World Factbook, Central Intelligence Agency, available at: https:// www.cia.gov/library/publications/the-world-factbook/appendix/appendix-b.html (accessed 11 September 2020).

Tomkins, C. and Carr, C. (1996), "Editorial in special issue of management accounting research: strategic management accounting", Management Accounting Research, Vol. 7 No. 2, pp. 165-167.

Turner, M.J., Way, S.A., Hodari, D. and Witteman, W. (2017), "Hotel property performance: the role of strategic management accounting”, International Journal of Hospitality Management, Vol. 63, pp. 33-43.

Zawawi, N.H.M. and Hoque, Z. (2010), "Research in management accounting innovations", Qualitative Research in Accounting and Management, Vol. 7 No. 4, pp. 505-568.

\section{Corresponding author}

Md. Mamunur Rashid can be contacted at: mamunrsub@gmail.com

For instructions on how to order reprints of this article, please visit our website:

www.emeraldgrouppublishing.com/licensing/reprints.htm

Or contact us for further details: permissions@emeraldinsight.com 